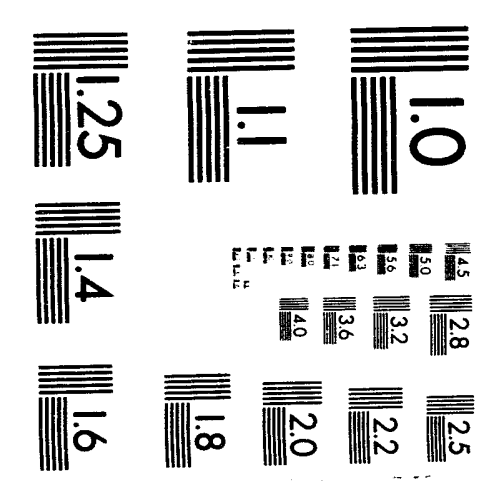



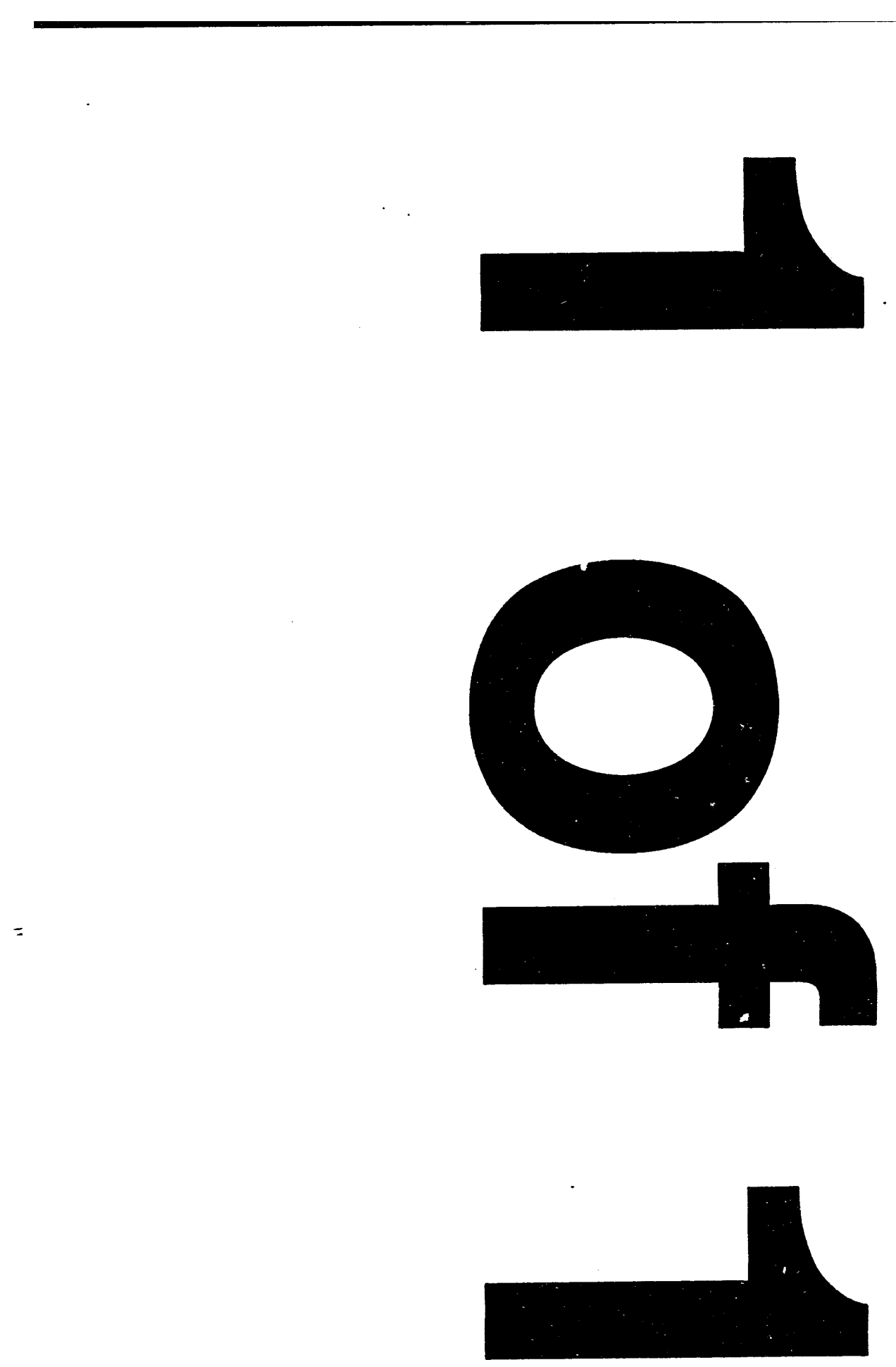
United States

Department of Energy

Semiannual Report

to Congress on

Inspector General

Audit Reports

April 1, 1993 to September 30, 1993

\section{November 1993}

Washington, DC 20585 


\section{U. S. Department of Energy}

\section{Semiannual Report to Congress on Inspector General Audit Reports}

For the Period April 1 through September 30, 1993

\section{TABLE OF CONTENTS}

FOREWORD .........................

INTRODUCTION $\ldots \ldots \ldots \ldots \ldots \ldots$

SIGNIFICANT AUDIT ACCOMPLISHMENTS $\ldots \ldots \ldots, \ldots, \ldots$

AUDIT REPORT STATISTICAL TABLES . . . . . . . . . . . . . 9

AUDIT REPORTS OPEN ONE YEAR

AFTER MANAGEMENT DECISION . . . . . . . . . . . . . 12 


\section{Foreword}

It is my pleasure to transmit to the Congress of the United States the Department of Energy's ninth Semiannual Report on Inspector General Audit Reports, in accordance with the 1988 Amendments to the Inspector General Act.

During this semiannual period we had an increased number of audit reports pending final action. Nonetheless, the Department reached decisions in $\mathbf{4 0}$ percent more cases and closed out 63 percent more cases than during the previous six months.

The Audit Resolution and Follow-up Program plays a key role in our overall quality effort by helping us focus on ways we can provide our customers with a more effective, efficient, and responsive Government. By constructive incorporation of improvements resulting from findings and recommendations developed by the Department's Inspector General, the General Accounting Office, and other audit organizations, we can provide a Government that works better and costs less.

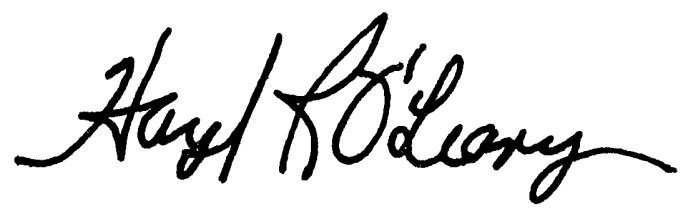

Hazel R. O'Leary

Secretary of Energy 


\section{Introduction}

This is the Secretary of Energy's ninth Semiannual Report to Congress to be submitted under the Inspector General Act of 1978, as amended. Pursuant to the Inspector General Act Amendments of 1988 (Public Law 100-504), agency heads are to report to Congress on the status of final action taken on audit report recommendations. This report complements a report prepared by the Department's Office of Inspector General that provides information on audit reports issued during the period and on the status of management decisions made on Inspector General audit reports.

During the period covered by this report, April 1 through September 30, 1993, the Department took final action on four contract and financial assistance audit reports. At the end of the period only three reports awaited final action. With regard to operational, financial, and preaward audits, final action was taken on 41 reports, resulting in 93 audit reports needing final action at the end of the period.

This report has three sections. The first outlines significant audit accomplishments achieved by the Department during the reporting period. The second section contains the statistical tables that illustrate the status of final action on Inspector General audit reports. The third lists the audit reports that are one year or more past management decision and have not completed final action. This section also provides the status of corrective actions on each of these reports. 


\section{Significant Audit Accomplishments}

During the period April 1 through September 30, 1993, management decisions were reached on 41 Inspector General reports and final actions were implemented on 45 other Inspector General Reports. Information is being provided on selected reports where audit action has been accomplished.

IG-0318, "Department-Wide Audit of Control and Management of Indirect Cost." During Fiscal Year 1991, the Department of Energy's management and operating contractors incurred indirect costs estimated at $\$ 4$ billion. The Inspector General found that the Department had not effectively administered management and operating contractors' indirect costs to ensure operating efficiency and compliance with cost accounting standards. In response to these findings, the Department issued a booster memorandum to its field offices to remind them that Departmental policy requires Field Chief Financial Officers to periodically review contractors' cost distribution systems to provide reasonable assurance that they are adequate to properly record and distribute labor, materials, other direct costs, and overhead expenses; similar overhead expenses are treated consistently throughout the organization; and, noncompliance or cost allocation issues that arise as a result of the reviews are resolved. We now treat overhead as a program, and we have implemented a system to monitor actual versus planned indirect costs at all our sites. In addition, the Chief Financial Officer Compliance Reviews have been expanded to include reviews of field organizations and management and operating contractors' compliance with this Departmental guidance.

IG-0320. "Disposal of Excess Capital Equipment at the Fernald Environmental Management Project, Fernald, Ohio." From 1953 to 1989 , a variety of uranium products designed for defense programs were produced at the Fernald Environmental Management Project. By 1988, demand for these products had declined and production was suspended in 1989. In February 1991, the Department decided to formally end production. Westinghouse Environmental Management Company of Ohio was responsible for managing and operating the Fernald Project. As a result of the audit finding that Westinghouse did not dispose of excess Government capital equipment in accordance with Federal and Department of Energy regulations and contract terms, the Department suspended sales until proper sales procedures could be implemented by the contractor. The Department has reviewed draft sales procedures developed by the contractor, recommended revisions, and is anticipating that the sales procedures will be final by year end, at which time the sales program will resume. 
IG-0323. "Review of DOE's Personnel Security Clearance Program." The Department of Energy personnel security clearance process seeks to ensure that persons allowed access to classified material are trustworthy, that granting a clearance will not endanger the common defense, and providing such access is consistent with the national interest. The Inspector General audited the personnel security clearance process at Headquarters and selected field sites and found the Department had not consistently followed established procedures for clearance terminations, initial justifications, and recertification of continuing clearance requirements; and, had granted security clearances to persons not specifically require to have access to classified material. In addressing the issues raised by the Inspector General, the Albuquerque and San Francisco Operations Offices have discontinued the practice of granting clearances based on the respective National laboratories' blanket clearance policies. In addition, the Department has reinforced the current policy on the security clearance process and has issued timeframe guidance to be followed in the resolution of derogatory information.

IG-0325, "DOE Management of High-Level Waste at the Hanford Site." For the past 50 years, the United States has generated radioactive waste through the production of nuclear materials for national defense. Approximately 60 million gallons of high-level radioactive waste are stored in underground tanks at the Department's Hanford Site, in Richland, Washington. Many of these tanks are known or are suspected to have leaked waste into the environment. The Department plans to resolve these environmental and safety concerns by retrieving the waste, immobilizing it, and disposing of it in a permanent geologic repository. The Inspector General found that the Department managed the Hanford remediation system as a number of separate projects not fully integrated into one major system acquisition and had not clearly defined requirements or developed overall cost and schedule baselines. To address the issues raised in the audit, the Department took immediate action to designate the Tank Waste Remediation System as a single major system acquisition. The Department also completed a previously initiated 15 month comprehensive rebaselining study which resulted in the Department proposing a revised technical strategy and a delay in the start of construction of the vitrification plant. In March 1993, the Department signed an "agreement in principle" with the Washington Department of Ecology and the U.S. Environmental Protection Agency to defer the start of construction of the waste vitrification plant for six months. During this six months a program to keep the public informed of the project will be implemented and negotiations addressing the new technical strategy will be conducted.

WR-B-93-1, Capital Equipment Purchased to Support the Environmental Restoration Program at the Hanford Site." The Inspector General conducted an audit to determine if the purchases of major capital equipment at the Hanford site were supportive of Hanford's mission and properly justified. The aunit disclosed that the Richland Operations Office and Westinghouse officials had not adequately considered the effects the purchase or non-purchase of captial equipment would have on program goals or whether there were loss costly solutions. The Richland Operations Office has since assessed Westinghouse Hanford Company's proposed procurement of about $\$ 6.6$ million of capital equipment to support the Environmental 
Restoration Program and now requires the development of an advance capital equipment acquisition plan that takes into consideration program goals. The Richland Operations Office has also directed Westinghouse to implement the principles of the DOE Order 4700.1, "Project Management System."

WR-OC-90-04, "Commercial Freight Carrier Selection and Invoice Verification Albuquerque Operations Office." The Inspector General reviewed the effectiveness of the Albuquerque Operations Office oversight of management and operating contractor selection of cost-favorable commercial freight carriers and verification of carrier invoices. The Inspector General found that the management and operating contractors at Albuquerque used higher cost carriers than necessary in 36 percent of the sample transactions and paid invalid charges 22 percent of the time. As a result of the audit, the Department has modified the management and operating contractors' contracts and now requires the contractors to use carriers that offer acceptable services at reduced rates.

IG-0272, "Indemnification of the Department of Energy's Management and Operating Contractors." The Inspector General found that it was the Department's general policy to indemnify its management and operating contractors and pay all costs associated with running the facilities managed by its contractors. The major exce'ptions to indemnification are costs that have been specifically identified in the contract as unallowable. There was some concern on the part of the Inspector General that the language in contracts related to nuclear activities was not clear as to the applicability of civil penalties to the management and operating contractors. In response, the Department issued a final rule which provides that Price-Anderson Act civil penalties are unallowable costs. In order to clarify this issue and strengthen the Department's control over the management and operating contractors, the Department published a final rule that makes "parent" corporations also liable for civil penalties under circumstances where losses or expenses result from the willful misconduct or lack of good faith on the part of key contractor personnel. 


\section{AUDIT REPORT STATISTICAL TABLE For the Period April 1 to September 30, 1993}

Total Number of Audit Reports (Contract and Financial Assistance) and the dollar value of disallowed costs:

Audit reports with management decisions

Number of Disallowed a

Reports

Costs

on which final action had not been taken

at the beginning of the period . . . . . . . . . . . . 4

$\$ 263,722$

Audit Reports on which management decisions

were made during the period:

Those issued after enactment of

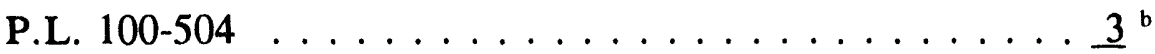

Total audit reports pending final action

during the period $\ldots \ldots \ldots \ldots$

$\$ 283,298$

Audit reports on which final action was taken

during the period:

Recoveries (Payments to Contractors). . . . . . . . . 4

Audit reports needing final action at the end

of the period $\ldots \ldots \ldots \ldots \ldots \ldots$

$\$ 326,557$

a The amount of costs questioned in the audit report with which the contracting officer concurs and has disallowed as a claim against the contract. Recoveries of disallowed costs are usually obtained by offset against current claims for payment and subsequently used for payment of other eligible costs under the contract.

b Agrees with the Inspector General's Semiannual Report to Congress for the same reporting period. 


\section{AUDIT REPORT STATISTICAL TABLE \\ For the Period April 1 to September 30, 1993}

Total Number of Audit Reports (Operational, Financial and Preaward) and the dollar value of recommendations that funds be put to better use agreed to by management in a management decision:

Number of

Reports

Audit reports with management decisions on which final

action had not been taken at the beginning of the period
Agreed Upon Funds Be Put To Better Use

$\$ 55,345,212$

Audit reports on which management decisions were made during the period:

Operational and Financial $\ldots \ldots \ldots \ldots \ldots$

Preawards ......................

$\$ 9,806,330$

129,471

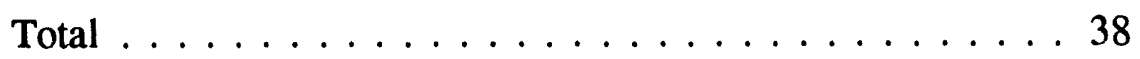

$\$ 9,935,801$

$\$ 65,281,013$

Total audit reports pending final action during period $\ldots \ldots \underline{134}$

Audit reports on which final action was taken during the period:

Operational and Financial . . . . . . . . . . . 40

Preawards ......................

Value of recommendations completed:

Operational and Financial $\ldots \ldots \ldots \ldots \ldots$

$\$ 9,861,824$

Preawards 129,471

Total ...................... . . .

$\$ 9.991,295$

Audit reports needing final action at the end of the period $\ldots \underline{\underline{93}}$ 
In addition to the $\$ 9,935,801$ in recommendations that funds be put to better use with which the Department agrees, there is $\$ 4,652,955$ with which the Department disagrees. This a.inount is associated with six operational audits. The Department partially agreed with the estimated amount of cost avoidance in two of these reports and disagreed entirely with the estimate in the other four reports. These amounts are displayed in a similar statistical table in the complementary Office of the Inspector General's Semiannual Report to Congress. 


\section{Inspector General Operational and Financial Audit and Inspection Reports \\ Open One Year or More After Management Decision \\ as of September 30, 1993}

\section{REPORT}

\section{HEADOUARTERS OFFICES}

\section{Administration and Management}

AD-91-002 ISSUED 09/05/91 (Management Decision 12/16/91) REPORT NUMBER: IG-0297

REPORT TITLE: Audit of Cost Etfectiveness of Contracting for Headquarters Support Services

(Agreed Upon Savings: $\$ 5,500,000$ )

\section{Civilian Radioactive Waste Management}

RW-87-001 ISSUED 10/10/86 (Management Decision 12/16/86) REPORT NUMBER: IG-0231

REPORT TITLE: Accuracy of Fees Paid by the Civilian Power Industry to the Nuclear Waste Fund
The Inspector General recommended that the Department develop a revised process for the review and approval of requests for contractor support services that would include a cost comparison analysis of federal versus contractor costs. Where the cost comparison supports conversion of the activity to federal service, the Inspector General recommended that a systematic process for coordinating with the Office of Management and Budget should be established to ensure that sufficient interim federal positions are available; additional staffing resources should be made by an adjustment to the Department's personnel base through the annual budget request. A revised process for the review and approval of requests for contractor support services has been established in DOE Order 4200.3D. A working group with representatives of the Department, Office of Management and Budget, General Accounting Office and Office of Federal Procurement Policy was established and has met to review the results of the Department's analyses to determine whether federal staff or contractors would be most cost effective for the performance of Headquarters support services. In addition, the Secretary's Contract Reform Task Force, established in June 1993, is examining this process and may recommend further changes.

The report stated that the Department did not have a contract with the State of New York for the disposal of high-level radioactive waste at West Valley and for the payment of fees for such disposal. The estimation of the share of disposal costs which should be assigned to New York has been developed. Discussions with representatives of New York, leading to a contract for the disposal of the nuclear waste, resumed in October 1991. Followup meetings have been delayed pending development of a joint Office of Civilian Radioactive Waste Management - Assistant Secretary for Environmental Restoration and Waste Management proposal on how to prioritize and time the several ongoing negotiations with New York. 


\section{REPORT}

RW-90-002 ISSUED 03/26/90 (Management Decision 07/11/90) REPORT NUMBER: IG-0280

REPORT TITLE: Followup of Fees Paid by the Civilian Power Industry to the Nuclear Waste Fund

RW-90-005 ISSUED 08/14/90 (Management Decision 02/22/91) REPORT NUMBER: IG-0287

REPORT TITLE: Credits Due the Department of Energy for Funding High Level Nuclear Energy Waste Management Research and Development

\section{Defense Programs}

DP-91-004 ISSUED 09/15/91 (Management Decision 12/23/91) REPORT NUMBER: IG-0296

REPORT TITLE: Departmentwide Audit of the Visibility Over the Status of Nuclear Materials

\section{Economic Impact and Diversity}

ED-92-001 ISSUED 11/15/91 (Management Decision 02/14/92) REPORT NUMBER: IG-0302

REPORT TITLE: Inspection of DOE's Equal Opportunity Complaint Processing System

\section{STATUS}

The report recommended that action be taken to ensure collection from utilities of the one-time fee for storage of spent nuclear fuel. DOE management and the Inspector General agreed that, as a first step, voluntary action by the utilities would be sought. The Office of Civilian Radioactive Waste Management met several times with the Edison Electric Institution and the National Association of Regulatory Utility

Commissioners to discuss the issue and in April 1991, chaired a meeting attended by representatives of those organizations, the DOE Inspector General, and several individual utilities. As a result of this meting, the Edison Electric Institution and the National Association of Regulatory Utility Commissioners volunteered to provide additional documentary information, that may not have been available to the Inspector General during this audit, which could contribute to resolution of this issue. The Department's analysis of the information provided by those organizations is expected to be completed by December 1993.

The report recommended that action be taken by the Office of Civilian Radioactive Waste Management and the Assistant Secretary for Environmental Restoration and Waste Management to complete a Memorandum of Understanding that includes criteria to be applied in determining eligibility for disposal fee credits. Once eligibility criteria are established, a system will be developed to identify all qualifying research and development activities, and to credit DOE for contributions to the Nuclear Waste Fund for those appropriated funds determined to have been spent on research and development projects that benefit the Office of Civilian Radioactive Waste Management programs. Senior management continues to pursue resolution of key issues regarding the Memorandum of Understanding.

The report concluded that the Department needs to make improvements in the nuclear management program and recommended strengthening the overall program and increasing the accuracy of the reporting systems. The Department agrees that improvements to the nuclear materials management program need to be made and is currently revising policy to ensure improvements in the quality of information, accuracy of reports and adherence to the revised policy. Final action is expected in December 1993.

The Inspector General found that the reporting relationships of some field office Equal Employment Opportunity managers was inappropriate; that organizational inefficiencies had delayed complaint processing; that counselors needed more training; and that Departmental policy needed updating. Corrective action is complete for five of the eight recommendations. The remaining three involve the revision of DOE Order 1600, "Equal Employment Authority," which was issued in Sentember 1992 in response to this report. The June 1993 DOE reorganization, as well as recent changes in Federal regulations and directives, require that the Order be further revised. 


\section{REPORT}

\section{Energy Information Administration}

EI-90-030 ISSUED 07/19/90 (Management Decision 04/09/91) REPORT NUMBER: CR-OC-90-02 REPORT TITLE: Procurement of Support Services for the Energy Information Administration

EI-91-031 ISSUED 09/30/91 (Management Decision 03/26/92) REPORT NUMBER: CR-B-91-02 REPORT TITLE: Selected Computer System Controls at the Energy Information Administration (Agreed Upon Savings: \$55,000)

\section{Energy Research}

ER-92-001 ISSUED 03/18/92 (Management Decision 07/29/92) REPORT NUMBER: IG-0305

REPORT TITLE: Followup Audit: Department of Energy's Superconducting Super Collider Program

\section{Environmental Restoration and Waste Management}

EM-91-002 ISSUED 01/02/91 (Management Decision 06/12/91) REPORT NUMBER: IG-0293 REPORT TITLE: Testing Laboratory Support to the Environmental Survey Program

\section{$\underline{\text { STATUS }}$}

The Inspector General found that the Energy Information Administration support service contracts may be suitable for fixed-priced or similar instruments, rather than the more commonly usea cost-plus-fixed-fee contract type. The Energy Information Administration is reviewing all support service contracts as they come up for renewal for opportunities to increase its use of fixed-price contracting. During this period, two opportunities for fixed-price contracting were identified and contracts awarded. All contract actions proposed will be documented regarding contract type to ensure consideration of fixed-price contracting opportunities. Final action is expected by September 1994.

The report stated that the Energy Information Administration needed more efficient disk space management at the Forrestal Computer Facility; proper storage and access to computer generated data; and a controlled maintenance process. Corrective action is complete on 11 of the 12 recommendations. Review and disposal of old data tape sets continues, with final action expected by December 1993.

This audit reviewed the Superconducting Super Collider program and made 12 recommendations for improvement of its operations. Corrective actions are complete on all but two of the recommendations, which pertain to the implementation of a Cost/Schedule Control System. This system will be fully functional when the policy statement is approved and certain refinements are completed. However, the Department is assessing the relevance of these actions to the termination of the Superconducting Super Collider program required by Public Law 103-126.

The Inspector General found that quality assurance standards were not effectively enforced and formal quality assurance guidance in operation and management oversight of contracted analytical laboratories was generally absent. The two recommendations still open require the development and implementation of adequate controls over future laboratory analysis of environmental samples through effective contractual agreements and management oversight of laboratory adherence to quality control requirements. Corrective actions on both recommendations are ongoing. DOE has developed a model contract technical statement of work designed to provide analytical services that meet user needs and assure the availability of data necessary to assess participant performance, which is under review. Quality assurance and assessment guidance has been developed and will be distributed to the field shortly. Also, a management assessment program will be piloted in FY 1994. Once this program is implemented, it will establish management oversight over laboratory quality control. Final action is estimated for March 1994. 


\section{REPORT}

EM-90-003 ISSUED 11/28/89 (Management Decision 05/26/90) REPORT NUMBER: IG-0278

REPORT TITLE: Departmentwide Audit of Carrier Selection and Invoice Verification

(Agreed Upon Savings: $\$ 3,200,000$ )

EM-9:-005 ISSUED 09/06/91 (Management Decision 01/16/92)

REPORT NUMBER: IG-0298

REPORT TITLE: Department of Energy's Waste Minimization Program

(Agreed Upon Savings: \$6,000,000)

EM-91-006 ISSUED 08/16/91 (Management Decision 01/07/92)

REPORT NUMBER: IG-0295

REPORT TITLE: Cost of Environmental Survey Testing

(Agreed Upon Savings: $\$ 3,300,000$ )

\section{STATUS}

The Inspector General found that DOE contracior/shippers were not consistent in following Federal regulations and DOE policy that commercial freight shipments be routed using carriers that can provide the required service at the lowest cost. More costly shipments and some excessive invoice payments occurred because DOE did not contractually require its shipping activities to use low-cost carriers and had not yet fully developed and established a Departmental automated transportation management program for processing shipping transactions and invoice payments. Corrective action on four of the five recommendations is complete. DOE is in the process of

developing and implementing the Automated Transportation Management System and the Electronic Data Interchange. During this period, the Integrated Logistics System a fully operational prototype for a module of the Automated Transportation

Management System, was deployed at nine additional test sites, bringing the total number of sites to fifteen throughout the DOE complex. Also, detailed design and construction of the Hazardous Materials Module of the Automated Transportation Management System was initiated. Activities continued in the development of the Electronic Data Interchange, including completion of testing with two major air express carriers; production data are now being received. Final action is expected in December 1995

The findings of this report were that the Department needed to establish a comprehensive waste minimization program to include procedures and appropriate funding to expeditiously eliminate or reduce the generation of radioactive and other hazardous wastes. The Department has made significant progress in developing and implementing a comprehensive waste minimization program. Policies have been established and expanded to enhance coordination and communication within the Department; waste minimization incentives are being provided; and, semiannual technology workshops have been developed. Final action is awaiting the issuance of final program guidance, which is expected by December 1993.

The report stated that the Department's environmental testing costs were substantially higher than the Environmental Protection Agency's costs for similar testing at its contract laboratories. The Inspector General found that DOE's costs were higher, in part, because management had not developed an acquisition strategy for procuring laboratory testing services. Instead of using competition through the procurement process, DOE used laboratories with which DOE had existing contracts. Corrective actions on one of the three recommendations is complete. DOE is in the process of developing an acquisition strategy to minimize costs for procuring further analytical testing services for DOE environmental programs, including both the development and enhancement of internal DOE laboratory capacity and acquisition strategy for obtaining the services of private, commercial labs. With regard to quality control requirements for analytical laboratories, a draft quality assurance requirement document, introducing the Analytical Services Quality Assurance Program has been distributed and comments are being incorporated. 


\section{Fossil Energy}

FE-92-003 ISSUED 02/14/92 (Management Decision 06/03/92) REPORT NUMBER: ER-BC-92-01

REPORT TITLE: Internal Controls Over Computer-Processed Financial Data at Boeing Petroleum Services

\section{Nuclear Energy}

NE-92-001 ISSUED 12/03/91 (Management Decision 07/18/92) REPORT NUMBER: IG-0304

REPORT TITLE: Concerns with the Effectiveness of the

Department's Quality Assurance Program Regarding Product Substitution Issues

\section{a}

\section{Procurement, Assistance and Program Management}

PR-87-004 ISSUED 06/01/87 (Management Decision 01/22/88) REPORT NUMBER: IG-0240

REPORT TITLE: Management and Operating Contractors`Pension Plans

PR-90-003 ISSUED 04/27/90 (Management Decision 04/27/90) REPORT NUMBER: IG-0281

REPORT TITLE: Inspection of the Lawrence Livermore National Laboratory’s Drug-Free Workplace Program
This audit found that Boeing's internal controls over its computer systems were not adequate. Of the 22 recommendations in the report, only one remains open. It pertains to finalization of an arrangement for backup computer support by an off-site computer facility. The Department has decided to use the Energy Information Administration facility in Washington, DC. The development of the backup agreement and testing of the plan is expected to be completed by August 1994 .

During its inspection of several DOE facilities, the Inspector General found suspected substandard parts in inventory and in use and concluded that the Department's efforts to resolve product substitution issues had not been successful. The report contained recommendations for a Department-wide approach to the development of policies, procedures and training on this issue, and for site specific actions. Corrective actions are complete on 7 of the 14 recommendations. Ongoing activities include the development of an overall plan, a training program, a Defense Programs manual and a periodic, DOE-wide information update and, an increase in the use of the DOE data base. Final action is expected by March 1994.

The findings of this report were that the Department needed to improve its oversight of management and operating contractor pension plans to reduce expenditures and to develop a policy to prevent contractors from unilaterally terminating pension plans and keeping excess assets. The Departmental policy on funding levels of contractor pension plans was revised to a goal of maintaining an equilibrium between assets and present value of accrued benefits. This policy was formally issued in a letter to all Operations Offices in November 1989. A second draft of DOE Order 3830.1, which establishes policy in all aspects of contractor pension plans, was coordinated within the Department and numerous comments were received. Outstanding issues have been resolved and the Order is under final management review, with issuance anticipated by September 1994 .

The Inspector General found that Lawrence Livermore National Laboratory did not have a random drug testing program and resommended that publication of the federal rules regarding the Personnel Security Assurance Program and the contractor DrugFree Workplace Program be expedited in order to provide the authority necessary for the DOE contractors' Human Reliability Program to fully function. The final rule, which incorporated all Human Reliability Program requirements became effective on August 21, 1992. The Inspector General recommendation that the Department assign central responsibility for the Human Reliability Program and establish a reporting system has also been accomplished. Final action is awaiting the clarification of DOE policy regarding the confidentiality of contractor employees' self-referral to the employee assistance program for substance abuse problems. This will be affected by a directive, which is expected to be issued by December 1993. 


\section{Security Affairs}

SA-85-001 ISSUED 09/30/85 (Management Decision 01/17/86) REPORT NUMBER: IG-0220

REPORT TITLE: Nuclear Safeguards and Security

SA-91-004 ISSUED 09/30/91 (Management Decision 01/30/92) REPORT NUMBER: IG-0299

REPORT TITLE: Inspection of Surveillance Equipment and Activities at the DOE Field Office, Richland

SA-92-003 ISSUED 11/21/91 (Management Decision 04/08/92) REPORT NUMBER: IG-0303

REPORT TITLE: Inspection of Work for Others Project at DOE Field Office Albuquerque

\section{FIELD OFFICES}

\section{Albuquerque Operations Office}

AL-91-017 ISSUED 09/27/91 (Management Decision 02/20/92) REPORT NUMBER: WR-B-91-08

REPORT TITLE: Review of Contractors' Personnel Security

Clearances at the DOE Field Office, Albuquerque
This is an extensive classified report on nuclear safeguards and security at DOE facilities. It had 83 recommendations, 78 of which have been closed to date. Action on several of the five recommendations still open has been delayed because it is dependent on the availability of funds for capital improvements at DOE racilities. The target date for final action on these remaining recommendations is March 1996.

The report addressed DOE surveillance activities which included procedures, training, types of surveillance equipment, and management controls over the equipment and activities. The two recommendations still open require that procedures be established concerning the acquisition, control, and disposition of equipment and the conduct of covert surveillances. The Department has developed policies and procedures which are presently being reviewed. Issuance is expected by December 1993.

The Inspector General addressed the need for additional procedural requirements to implement DOE Orders, improve management coordination, and improve associated documentation; analysis of current procurement and security regliations and policies; and, establishing and publishing a DOE policy on the conduct of polygraph examinations in certain circumstances associated with intelligence related activities. The review of current regulations and policies is complete; revisions are being made and new requirements are being drafted. Final action is expected by March 1994.

The recommendation in this report was that the Albuquerque Field Office should reevaluate the need for " $Q$ " security clearances held by managentent and operating contractor employees, and if the clearances cannot be appropriately justified, direct that such clearances be downgraded or terminated. The Defartment has evaluated the justification: for management and operating contractors security clearances;

established policy requiring that clearances be granted based on the level of access needed to perform specific functions; and, directed contractors to develop action plans to reduce the number and level of security clearances. The Department continues to monitor performance against those plans. Final action is planned by September 1994. 


\section{REPORT}

AL-91-018 ISSUED 09/27/91 (Management Decision 01/13/92) REPORT NUMBER: WR-B-91-09

REPORT TITLE: Audit of New Mexico Gross Receipts Taxes Paid

by DOE Field Office, Albuquerque, Management and Operating Contractors

AL-91-019 ISSUED 09/30/91 (Management Decision 12/06/91) REPORT NUMBER: WR-BC-91-02

REPORT TITLE: Report on Financial Administration of Work for Non-Federal Sponsors, DOE Field Office, Albuquerque

AL-92-002 ISSUED 02/20/92 (Management Decision 06/03/92) REPORT NUMBER: ER-B-92-02

REPORT TITLE: EG\&G Mound Applied Technologies Payroll System

\section{Bonneville Power Administration}

BP-92-001 ISSUED 01/13/92 (Management Decision 03/23/92) REPORT NUMBER: WR-B-92-01

REPORT TITLE: Audit of Environmental Training at the

Bonneville Power Administration, Portland, Oregon

\section{STATUS}

In this report, the Inspector General found that the Albuquerque Field Office did not have the necessary procedures to review its management and operating contractor practices regarding gross receipts taxes. Albuquerque has directed its contractors to establish procedures to ensure Resale of Services Certificates are issued and, when appropriate, reviews management and operating contractor compliance with the New Mexico Gross Receipts Tax Act. In addition, contractors were directed to establish procedures to ensure claimed deductions and exclusions from gross receipts are substantiated and a followup review is performed on procedures instituted for computing its gross receipts tax. Appropriate procedures have been developed and are under review by the State of New Mexico. Final action is expected by March 1994.

Federal laws and regulations requirer the Department to aggressively pursue collecting amounts owed the Government. Corrective action on seven of the eight recommendations is completed. The Inspector General recommended that the Albuquerque Operations Office obtain an Office of General Counsel opinion on whether the Federal Claims Collection Standards apply to the Mesa Diagnostics fundsin agreement. Albuquerque provided a written request for an opinion from the Office of General Counsel on September 30,1992. The issue is being analyzed and the target completion date is December 1993.

This audit found that the contractor, EG\&G, had poor internal controls over its payroll system. Corrective action is complete on three of the five recommendations. Implementation of the separation of duties and restriction of access to payroll data files is expected by March 1994.

The finding in this report was that the Bonneville Power Administration had not complied with all Occupational Safety and Health Administration, Department of Energy, and Bonneville Power Administration requirements for environmental training and recordkeeping. Corrective action on four of the five recommendations is complete. An adjustment to the Automated Training System has been made to allow direct input of training information and an assessment of Bonneville's requirements for recording training and documentation activities. Enhancements to the training system are complete. However, compatibility between the Automated Training System and the Safety Training and Records System is being developed to ensure that both environmental and safety training are accurately recorded. Final action on the remaining recommendation is expected by December 1993. 


\section{Chicago Operations Office}

CH-89-098 ISSUED 08/08/89 (Management Decision 05/29/90) REPORT NUMBER: ER-OC-89-17

REPORT TITLE: The Accounting System at Princeton Plasma Physics Laboratory

CH-90-156 ISSUED 09/18/90 (Management Decision 03/21/91) REPORT NUMBER: ER-O-90-08

REPORT TITLE: Environmental Controls at Argonne National Laboratory
The report recommended that the Princeton Plasma Physics Laboratory close out the Tokomak Fusion Test Reactor construction project and, following the receipt of final audit reports, adjust asset and accumulated depreciation balances accordingly.

Subcontracts for the project remained open pending audit negotiations for overhead rate determinations. Audit coverage was requested from the Office of Inspector General, which in turn advised the Defense Contract Audit Agency to perform the needed audits. Since no audit has been performed, DOE reconciled the accounting records of the Princeton Plasma Physics Laboratory and the subcontractor. Final action is awaiting resolution of indirect cost rates, which is expected by March 1994.

The Inspector General found that Argonne National Laboratory's process for identifying and obtaining permits was not adequate to ensure compliance with required laws; management of hazardous waste was not adequate to ensure compliance with Federal, State and local laws and regulations; and, DOE oversight of Argonne National Laboratory was limited and did not assure environmental compliance. Policies and procedures have been implemented for identifying and obtaining permits in a timely manner and a comprehensive survey of environmental permits required at the Argonne site has been completed. Followup and verification procedures to ensure Argonne's compliance with applicable environmental laws and regulations have been strengthened and a comprehensive environmental protection appraisal was conducted, with resulting corrective actions being tracked to closure. Minor construction projects to design, rehabilitate, and construct mixed waste storage facilities are dependent on future funding availability.

The report contained recommendations for the improvement of Brookhaven National Laboratory's environmental compliance in the areas of personnel training, sewer system maintenance, and permit compliance. Several of the corrective actions are complete, including hazardous waste training of all pertinent staff and the development of a process to establish a complete inventory of liquid emission points. The results of an effluent survey were analyzed and effluent points were then prioritized for followup sampling, which was conducted. Chemical analysis of the effluents is complete and a draft report is expected by December 1993.

The report found that the management and operating contractors at DOE's Oak Ridge facilities had not identified the Federal excise tax 1 efunds available for fuel purchased for off-highway business use or applied for the refunds as permitted by the Internal Revenue Service. The recommendation was that Oak Ridge should direct its contractors to implement written policies and procedures to estimate the amount of fuel used off-highway and ensure that claims are filed annually, as well as estimate and file for refunds for tax years 1988 through 1990 . All the contractors have implemented the written policies and procedures. All but one contractor has filed for a refund for the prior tax years. Final action is expected in December 1993.
OR-92-035 ISSUED 02/18/92 (Management Decision 06/18/92) REPORT NUMBER: ER-B-92-01

REPORT TITLE: Federal Excise Refunds for Contractors of (Agreed Upon Savings: $\$ 562,400$ ) 


\section{San Francisco Operations Office}

SF-90-006 ISSUED 09/28/90 (Management Decision 09/30/91) REPORT NUMBER: IG-0290

REPORT TITLE: General Management Inspection of the San Francisco Operations Office

SF-91-004; ISSUED 03/11/91 (Management Decision 09/19/91) REPORT NUMBER: WR-VC-91-22

REPORT TITLE: Internal Controls That Assure FY 1989 Costs Claimed By and Reimbursed to Stanford Linear Accelerator (SLAC) are Allowable Under DOE Contract No. DE-AC03-76SF00515

\section{COST ALLOWABILITY AUDITS}

SF-91-011 ISSUED 09/23/91 (Management Decision 01/22/92) REPORT NUMBER: WR-V-91-05

REPORT TITLE: Internal Controls That Assure FY 1991 Costs Claimed By and Reimbursed to Lawrence Berkeley Laboratory are Allowable Under Department of Energy Contract DE-AC03-76SF0098

SF-91-001 ISSUED 03/01/91 (Management Decision 07/09/91) REPORT NUMBER: WR-V-91-01

REPORT TITLE: Internal Controls That Assure FY 1990 Costs Claimed By and Reimbursed to Lawrence Berkeley Laboratory are Allowable Under Department of Energy Contract

DE-AC03-76SF0098
The Inspector General performed a general management inspection of the San Francisco Operations Office and made recommendations in the areas of management and operating contract management, administration, environment and safety, quality assurance, facilities and management services, energy programs, defense programs, and general management of the Operations Office. Because a number of the Inspector General's findings related to implementation of DOE policies and procedures, some recommendations were addressed to Headquarters organizations. Of the 65 recommendations, 13 still require corrective action. Implementation of several recommendations were completed with the signing of the management and operating contract with the University of Califormia. Other corrective actions remaining are longer term in nature.

The Inspector General recommended that DOE ensure that property controls are in place which will protect the Department's assets at the Stanford Linear Accelerator. Property Management Instructions were issued to Stanford which conform to the DOE and Federal Management Regulation requirements. A Personal Property Management Review was conducted in 1992 and a report issued which gave Stanford's Property Management System an overall rating of marginal. As a result of this report, a revised corrective action plan was prepared which addressed the tasks and proposed actions required to remedy the deficiencies. A meeting between San Francisco and Stanford management is scheduled for the fourth quarter of 1993 to discuss concerns regarding remaining deficiencies and evaluate progress to date in completing milestones. Final action is anticipated by June 1994.

The Inspector General found that the management and operating contractor had not conducted adequate internal audits of costs claimed. The audits are being conducted and, when completed, will be provided to the Inspector General for approval. Final action will occur when the reports are accepted by the Inspector General. 
SF-91-006 ISSUED 03/01/91 (Management Decision 07/09/91) REPORT NUMBER: WR-VC-91-25

REPORT TITLE: Internal Controls That Assure FY 1989 Costs Claimed By and Reimbursed to Lawrence Berkeley Laboratory are Allowable Under Department of Energy Contract

DE-AC03-76SF0098

SF-91-003 ISSUED 03/06/91 (Management Decision 07/15/91) REPORT NUMBER: WR-V-91-03

REPORT TITLE: Internal Controls That Assure FY 1990 Costs Claimed By and Reimbursed to Lawrence Livermore National Laboratory are Allowable Under Department of Energy Contract W-7405-ENG-48

SF-91-005 ISSUED 03/01/91 (Management Decision 07/15/91) REPORT NUMBER: WR-VC-91-24

REPORT TITLE: Internal Controls That Assure FY 1989 Costs Claimed By and Reimbursed to Lawrence Livermore National Laboratory are Allowable Under Department of Energy Contract

W-7405-ENG-48

SF-92-001 ISSUED 03/25/92 (Management Decision 08/06/92) REPORT NUMBER: WR-V-92-09

REPORT TTTLE: Internal Controls That Assure FY 1991 Costs Claimed By and Reimbursed to Lawrence Livermore National Laboratory are Allowed Under Department of Energy Contract

W-7405-ENG-48

ID-92-001 ISSUED 12/21/91 (Management Decision 06/18/92) REPORT NUMBER: WR-V-92-05

REPORT TITLE: Internal Controls That Assure Fiscal Year 1991 Costs Claimed By and Reimbursed to Rockwell-INEL are Allowable Under Department of Energy Contract No.DE-AC06-90RL1171

RL-92-001 ISSUED 10/28/91 (Management Decision 10/28/91) REPORT NUMBER: WR-VC-92-01

REPORT TITLE: Internal Controls That Assure Fiscal Year 1991 Costs Claimed By and Reimbursed to Battelle Pacific NW Labs are Allowable Under DOE Contract

DE-AC07-76RL01830
Same as above

Same as above

Same as above

Same as above

Same as above

Corrective actions have been performed and management is in the process of evaluating the effectiveness of the corrective action prior to requesting a final review by the Inspector General. 


\section{REPORT}

RF-91-002 ISSUED 03/11/91 (Management Decision 06/10/91) REPORT NUMBER: WR-VC-91-38

REPORT TITLE: Internal Controls That Assure Fiscal Year 1990 Costs Claimed By and Reimbursed to Rockwell International

Corporation and EG\&G Rocky Flats, Inc. are Allowable Under DOE Contract DE-AC04-76DP03533 and DE-AC04-90DP62349

RF-91-001 ISSUED 03/01/91 (Management Decision 06/10/91) REPORT NUMBER: WR-VC-91-30

REPORT TITLE: Internal Controls That Assure Fiscal Year 1989 Costs Claimed By and Reimbursed to Rockwell International

Corporation are Allowable Under DOE Contract

DE-AC04-76DP03533

RF-92-002 ISSUED 03/17/92 (Management Decision 09/22/92) REPORT NUMBER: WR-V-92-08

REPORT TITLE: Internal Controls That Assure Fiscal Year 1991 Costs Claimed By and Reimbursed to EG\&G Rocky Flats, Inc. are Allowable Under DOE Contract DE-AC04-90DP62349

\section{LITIGATION}

ID-90-006 ISSUED 12/19/89 (Management Decision 02/13/91) REPORT NUMBER: WR-O-90-01

REPORT TITLE: Unrecovered Costs on Interagency Agreement No. TV-68345A Between the Tennessee Valley Authority and the Idaho Operations Office

(Agreed Upon Savings: \$3,253,510)

OR-92-057 ISSUED 04/16/92 (Management Decision 07/27/92)

REPORT NUMBER: IG-0307

REPORT TITLE: Procurement of Services from 8(a) Contractors

for the Work-for-Others Program

(Agreed Upon Savings: \$151,743)

SF-87-004 ISSUED 08/10/87 (Management Decision 04/01/88)

REPORT NUMBER: IG-0243

REPORT TITLE: The Department of Energy's Collection

Procedures for Defaulted Geothermal Loan Guarantees

\section{STATUS}

The Inspector General found that the management and operating contractor had not conducted adequate internal audits of costs claimed. The audits have been performed and the audit reports issued and provided to the Inspector General. The Inspector General requires additional work to be performed by the internal auditors before the audits can be approved.

Same as above

A cost estimate to implement the necessary corrective actions has been developed and provided to the Inspector General. The Inspector General, EG\&G and Rocky Flats management are scheduled to meet to discuss actions necessary to arrive at a final resolution of the two remaining recommendations.

This report is currently in litigation.

Same as above

Same as above

NOTE: the amount agreed to in parenthesis under the report title. 



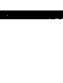

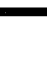

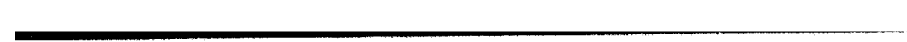

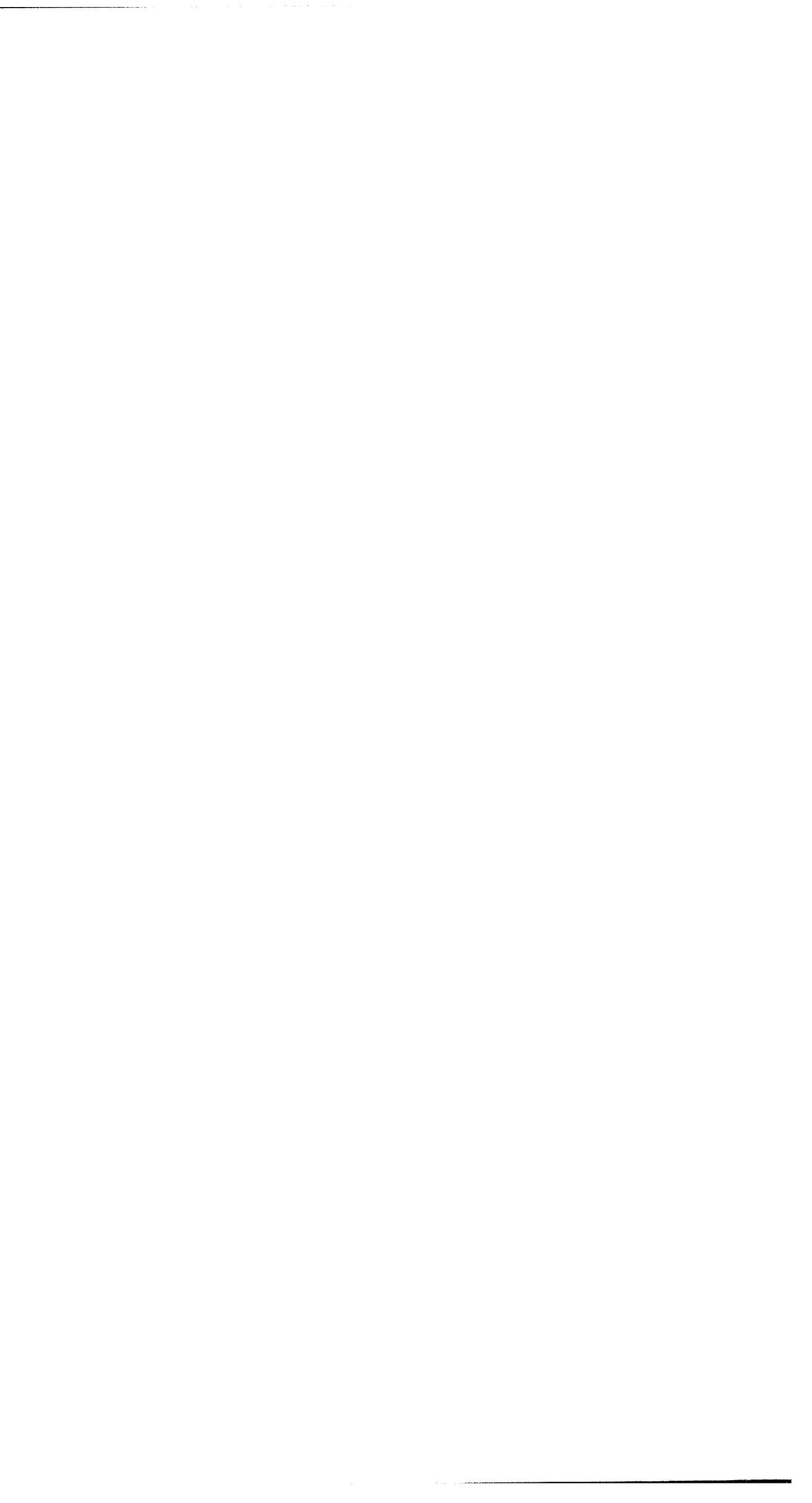

